\title{
Spectroscopic and Electrochemical Trends in Divalent Lanthanides through Modulation of Coordination Environment
}

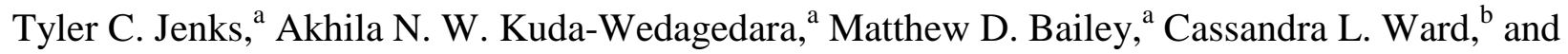
Matthew J. Allen ${ }^{\mathrm{a}, *}$

${ }^{a}$ Department of Chemistry, Wayne State University, 5101 Cass Avenue, Detroit, Michigan 48202, United States.

${ }^{b}$ Lumigen Instrument Center, Wayne State University, 5101 Cass Avenue, Detroit, Michigan 48202, United States.

*E-mail: mallen@chem.wayne.edu

\begin{tabular}{lll}
\hline Page & Contents \\
\hline S1 & Table of Contents \\
S2-S5 & Crystallographic Data \\
S6-S7 & ${ }^{1}$ H-NMR Spectra \\
S8-S9 & UV-Visible Spectra \\
S10-S12 & Excitation and Emission Spectra \\
S13-S16 & Cyclic Voltammograms \\
\hline
\end{tabular}


Jenks et al.

Supporting Information

\section{Crystallographic Data}

\section{Table S1. Crystallographic properties of $\mathrm{Yb}^{\mathrm{II}} 1$.}

\begin{tabular}{lll}
\hline Chemical formula & $\mathrm{C}_{18} \mathrm{H}_{36} \mathrm{I}_{2} \mathrm{~N}_{2} \mathrm{O}_{6} \mathrm{Yb}$ & \\
Formula weight & 803.33 & \\
$\mathrm{R}_{1}$ & $9.24 \%$ & \\
$\mathrm{wR}_{2}$ & $20.13 \%$ & \\
Goodness of Fit & 1.044 & \\
Largest residual peak/hole & $4.32 /-2.32$ & \\
Temperature & $100.1 \mathrm{~K}$ & \\
Wavelength & $0.71073 \AA$ & \\
Crystal system & monoclinic & \\
Space group & $P 2 / \mathrm{c}$ & $\alpha=90^{\circ}$ \\
Unit cell dimensions & $\mathrm{a}=14.5368(17) \AA$ & $\beta=9.441(8)^{\circ}$ \\
& $\mathrm{b}=9.5302(10) \AA$ & $\AA$ \\
& $\mathrm{c}=17.928(2) \AA$ & $\gamma 0^{\circ}$ \\
Volume & $2483.6(5) \AA^{3}$ & \\
$\mathrm{Z}$ & 4 \\
Density (calculated) & $2.148 \mathrm{~g} / \mathrm{cm}^{3}$ & \\
Absorption coefficient & $6.285 \mathrm{~mm}^{-1}$ & \\
F(000) & 1528.0 & \\
\hline
\end{tabular}


Table S2. Crystallographic properties of $\mathbf{Y b}^{\mathrm{II}} 2$.

\begin{tabular}{lll}
\hline Chemical formula & $\mathrm{C}_{22} \mathrm{H}_{36} \mathrm{I}_{2} \mathrm{~N}_{2} \mathrm{O}_{6} \mathrm{Yb}$ & \\
Formula weight & 851.37 & \\
$\mathrm{R}_{1}$ & $2.01 \%$ & \\
$\mathrm{wR}_{2}$ & $4.73 \%$ & \\
Goodness of Fit & 1.043 & \\
Largest residual peak/hole & $1.5 /-1.1$ & \\
Temperature & $100.1 \mathrm{~K}$ & \\
Wavelength & $0.71073 \AA$ & \\
Crystal system & monoclinic & \\
Space group & $P 2{ }_{1} / \mathrm{c}$ & \\
Unit cell dimensions & $\mathrm{a}=12.7289(6) \AA$ & $\alpha=90^{\circ}$ \\
& $\mathrm{b}=12.1762(6) \AA$ & $\beta=98.778(3)^{\circ}$ \\
& $\mathrm{c}=17.4932(9) \AA$ & $\gamma=90^{\circ}$ \\
Volume & $2679.5(2) \AA^{3}$ & \\
$Z$ & 4 \\
Density (calculated) & $2.110 \mathrm{~g} / \mathrm{cm}^{3}$ & \\
Absorption coefficient & $5.832 \mathrm{~mm}^{-1}$ & \\
F(000) & 1624.0 & \\
\hline
\end{tabular}


Table S3. Crystallographic properties of $\mathbf{Y b}^{\mathrm{II}} 3$.

\begin{tabular}{lll}
\hline Chemical formula & $\mathrm{C}_{18} \mathrm{H}_{42} \mathrm{I}_{2} \mathrm{~N}_{8} \mathrm{Yb}$ & \\
Formula weight & 797.42 & \\
$\mathrm{R}_{1}$ & $1.86 \%$ \\
$\mathrm{wR}_{2}$ & $4.94 \%$ \\
Goodness of Fit & 1.333 & \\
Largest residual peak/hole & $1.2 /-4.1$ & \\
Temperature & $100.1 \mathrm{~K}$ & \\
Wavelength & $0.71073 \AA$ & $\alpha=90^{\circ}$ \\
Crystal system & trigonal & $\beta=90^{\circ}$ \\
Space group & $P \overline{3} 1 \mathrm{c}$ & $\gamma=120^{\circ}$ \\
Unit cell dimensions & $\mathrm{a}=9.4352(7) \AA$ & \\
& $\mathrm{b}=9.4352(7) \AA$ & \\
& $\mathrm{c}=16.6737(14)) \AA$ & \\
Volume & $1285.5(2) \AA \AA^{3}$ & \\
$\mathrm{Z}$ & 2 & \\
Density (calculated) & $2.060 \mathrm{~g} / \mathrm{cm}^{3}$ & \\
Absorption coefficient & $6.060 \mathrm{~mm}^{-1}$ & \\
F(000) & 764.0 & \\
\hline
\end{tabular}


Table S4. Crystallographic properties of $\mathbf{Y b}^{\mathrm{II}} 4$.

\begin{tabular}{lll}
\hline Chemical formula & $\mathrm{C}_{24} \mathrm{H}_{54} \mathrm{I}_{2} \mathrm{~N}_{8} \mathrm{Yb}$ & \\
Formula weight & 881.60 & \\
$\mathrm{R}_{1}$ & $1.59 \%$ & \\
$\mathrm{wR}_{2}$ & $4.16 \%$ & \\
Goodness of Fit & 0.928 & \\
Largest residual peak/hole & $1.2 /-1.1$ & \\
Temperature & $100.1 \mathrm{~K}$ & $\alpha=90^{\circ}$ \\
Wavelength & $0.71073 \AA$ & $\beta=90^{\circ}$ \\
Crystal system & $\mathrm{cubic}$ & $\gamma=90^{\circ}$ \\
Space group & $P 2{ }_{1} 3$ & \\
Unit cell dimensions & $\mathrm{a}=14.7634(8) \AA$ \\
& $\mathrm{b}=14.7634(8) \AA$ & \\
& $\mathrm{c}=14.7634(8) \AA$ & \\
Volume & $3217.8(5) \AA^{3}$ & \\
$\mathrm{Z}$ & 4 \\
Density (calculated) & $1.820 \mathrm{~g} / \mathrm{cm}^{3}$ & \\
Absorption coefficient & $4.851 \mathrm{~mm}^{-1}$ & \\
F(000) & 1720.0 & \\
\hline
\end{tabular}


Jenks et al.

\section{${ }^{1}$ H-NMR Spectra}

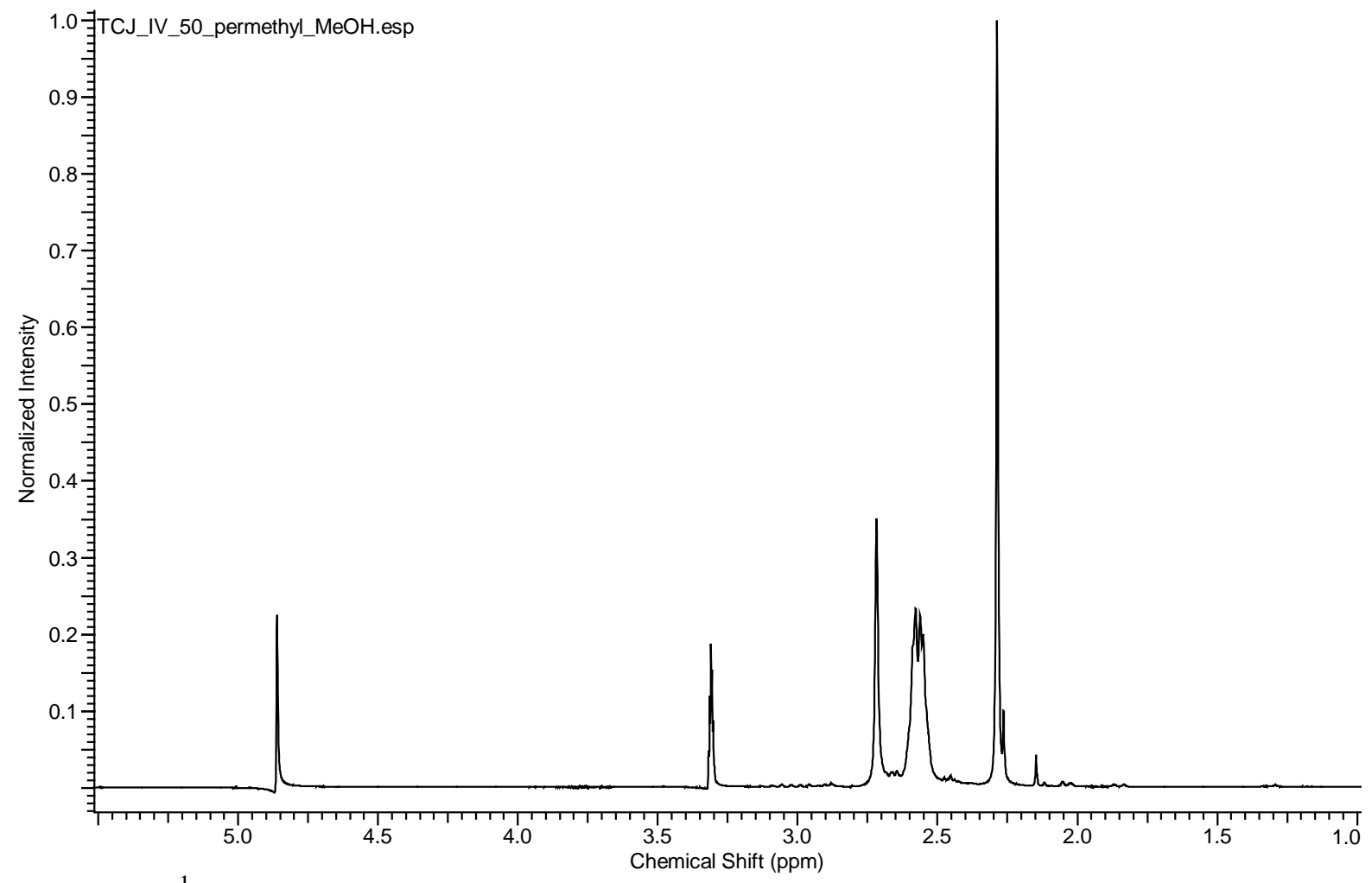

Figure S1. ${ }^{1} \mathrm{H}$-NMR spectrum of cryptand $\mathbf{4}$ in $d_{4}$-methanol.

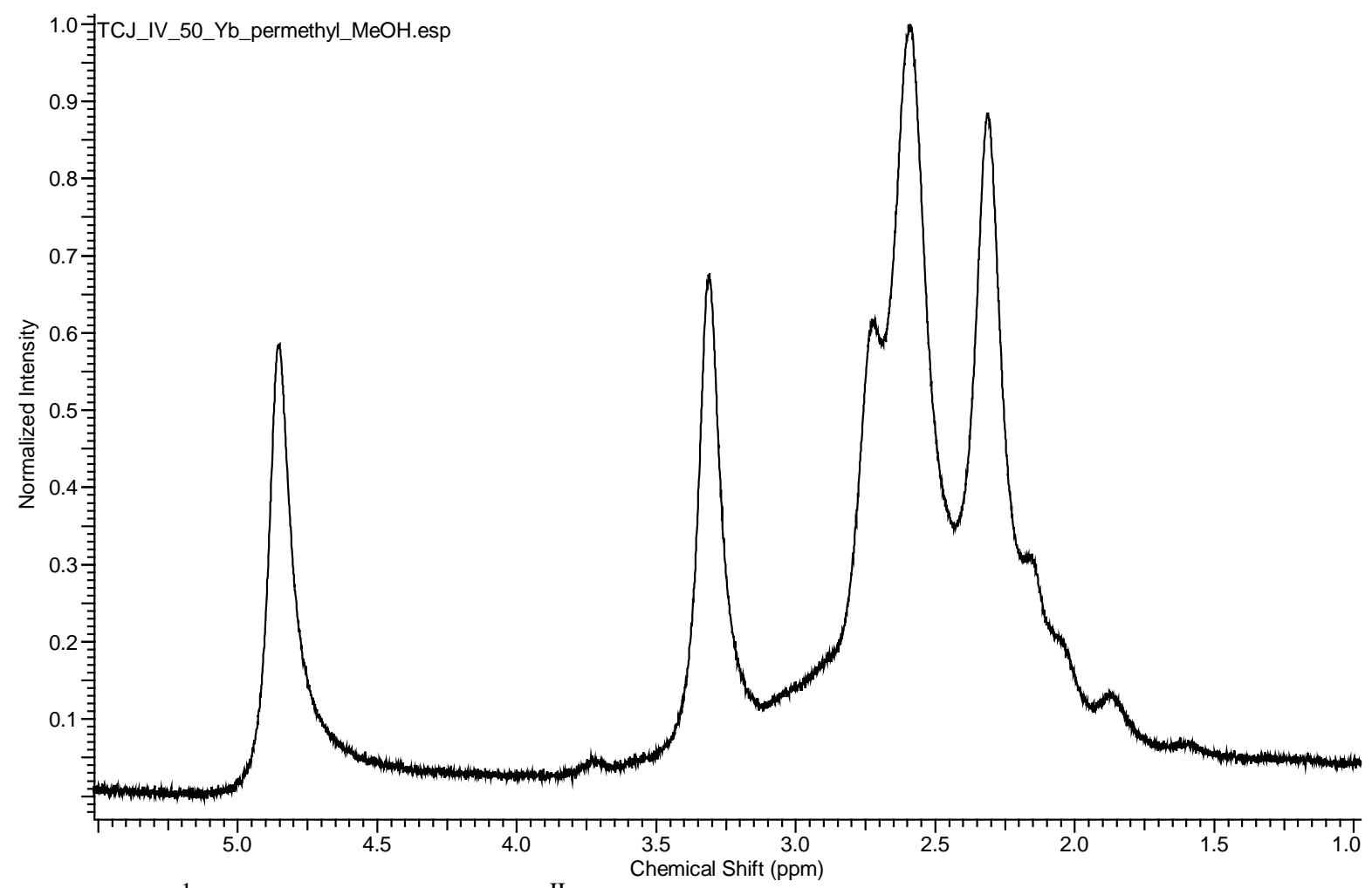

Figure S2. ${ }^{1} \mathrm{H}-\mathrm{NMR}$ spectrum of $\mathrm{Yb}^{\mathrm{II}} \mathbf{4}$ in $d_{4}$-methanol. 
Jenks et al.

Supporting Information

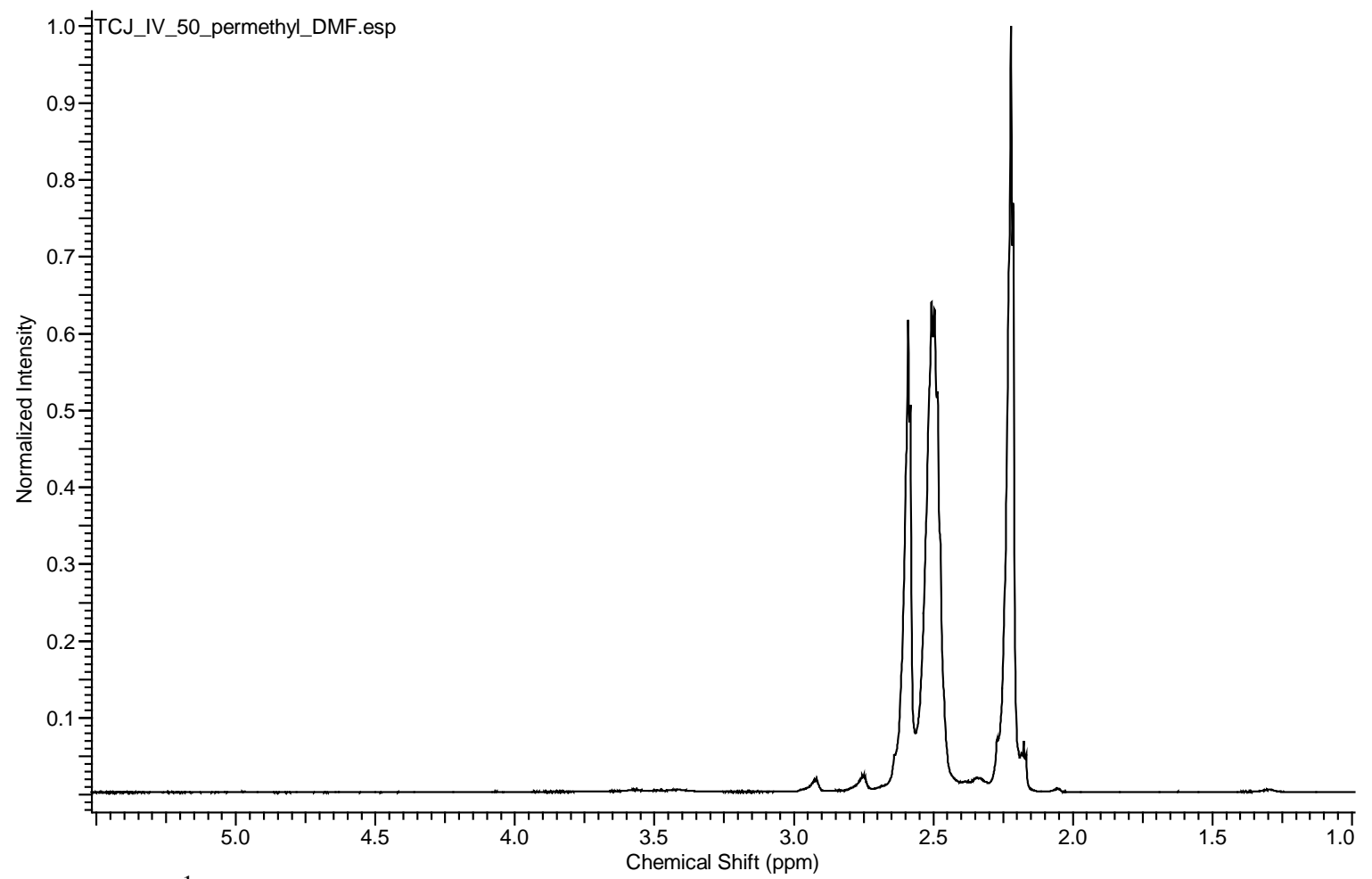

Figure S3. ${ }^{1} \mathrm{H}-\mathrm{NMR}$ spectrum of cryptand $\mathbf{4}$ in $N, N$-dimethylformamide- $d_{7}$.

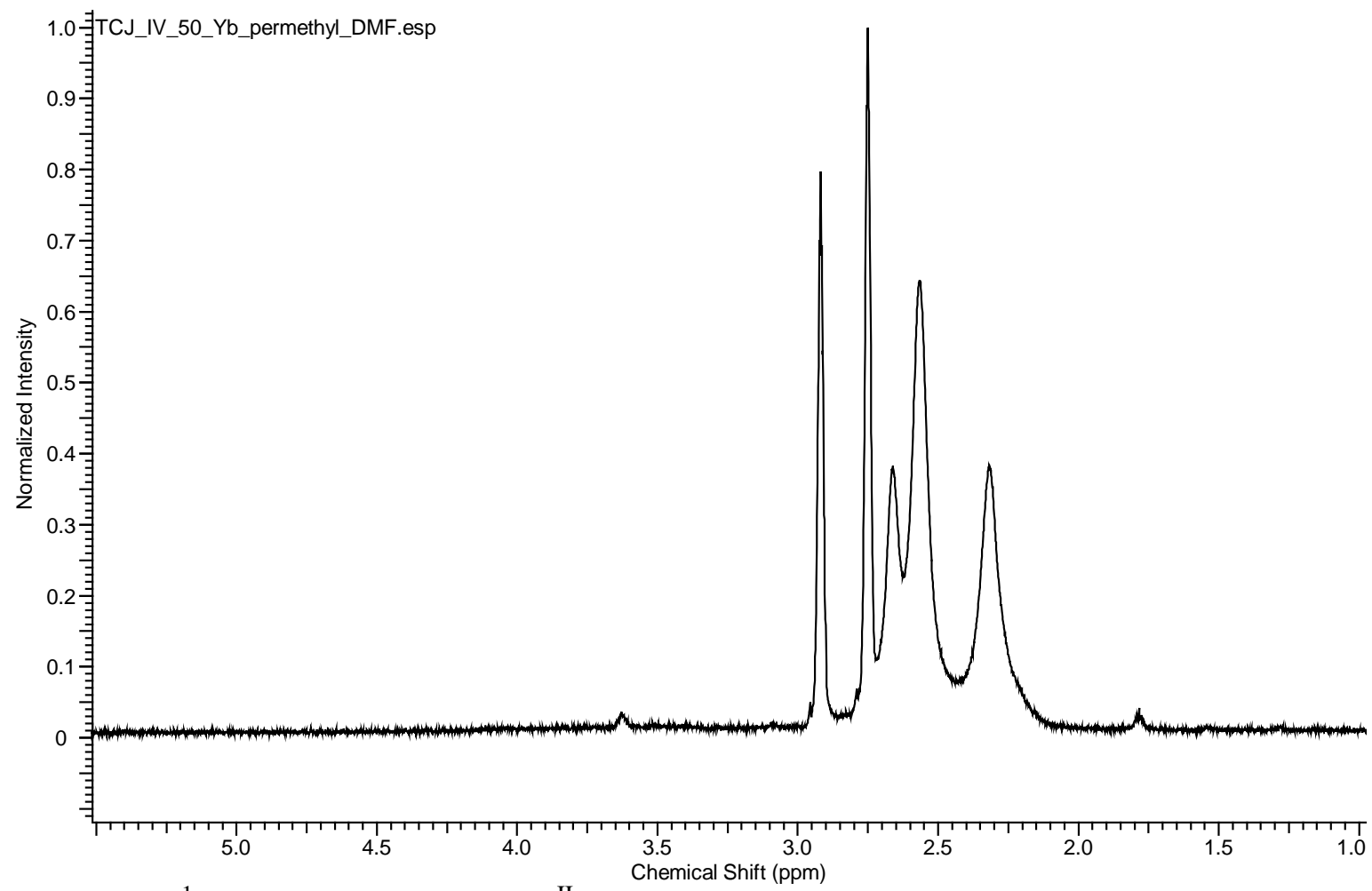

Figure S4. ${ }^{1} \mathrm{H}-\mathrm{NMR}$ spectrum of $\mathrm{Yb}^{\mathrm{II}} \mathbf{4}$ in $N, N$-dimethylformamide- $d_{7}$. 


\section{UV-Visible Spectra}

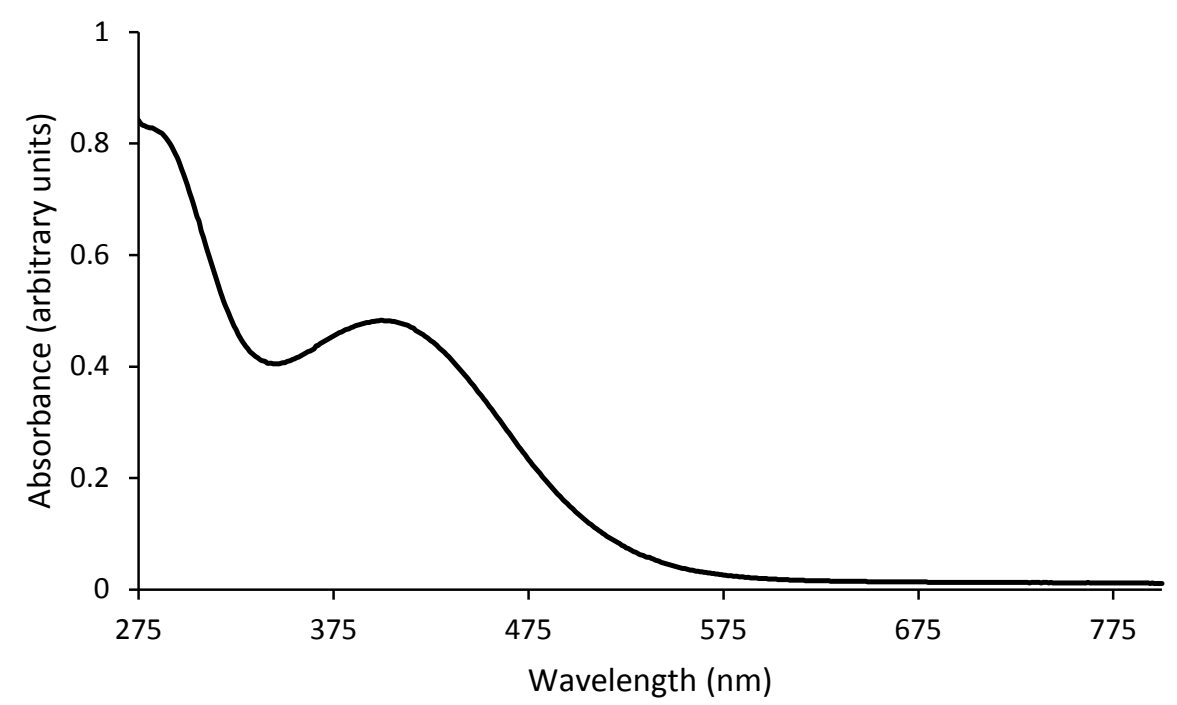

Figure S5. UV-visible spectrum of $\mathrm{YbI}_{2}$ in $N, N$-dimethylformamide.

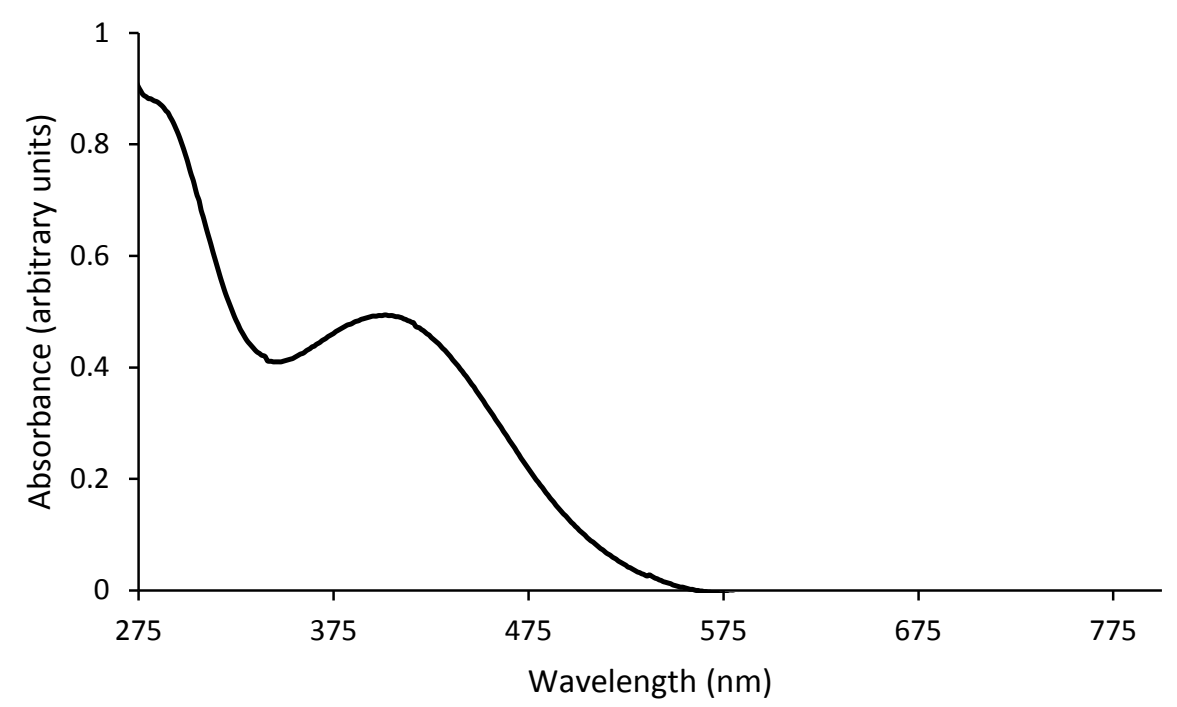

Figure S6. UV-visible spectrum of $\mathrm{Yb}^{\mathrm{II}} \mathbf{4}$ in $N, N$-dimethylformamide. 


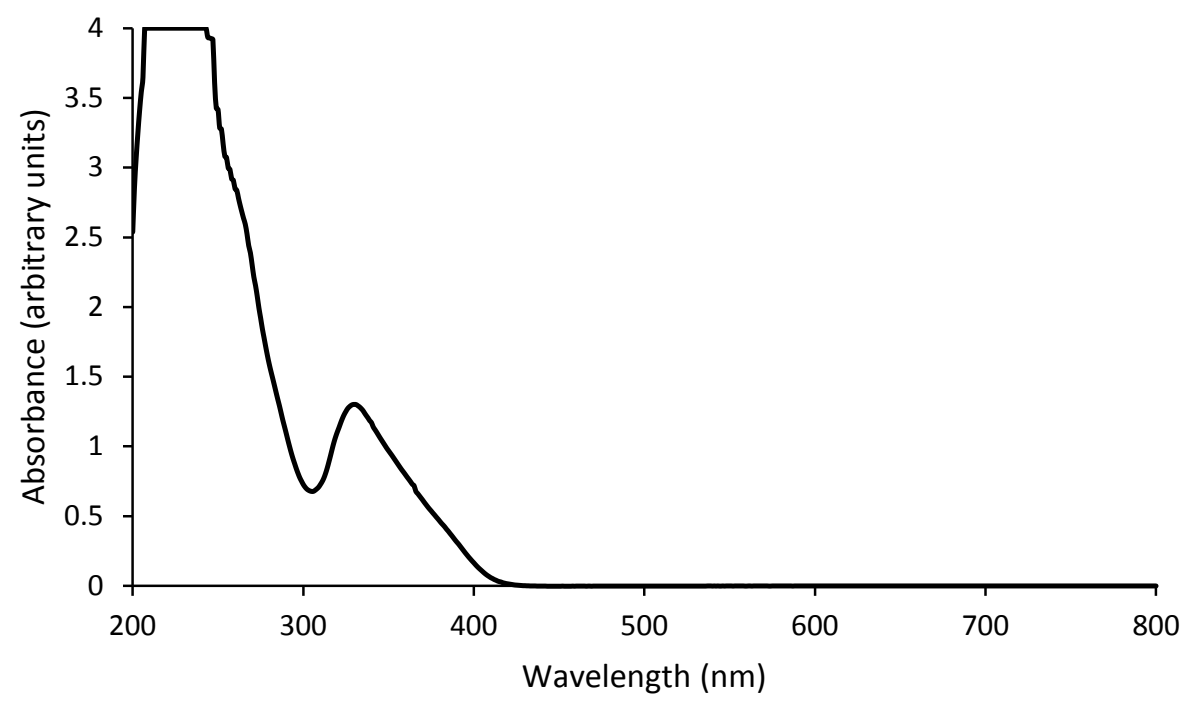

Figure S7. UV-visible spectrum of $\mathrm{EuI}_{2}$ in methanol.

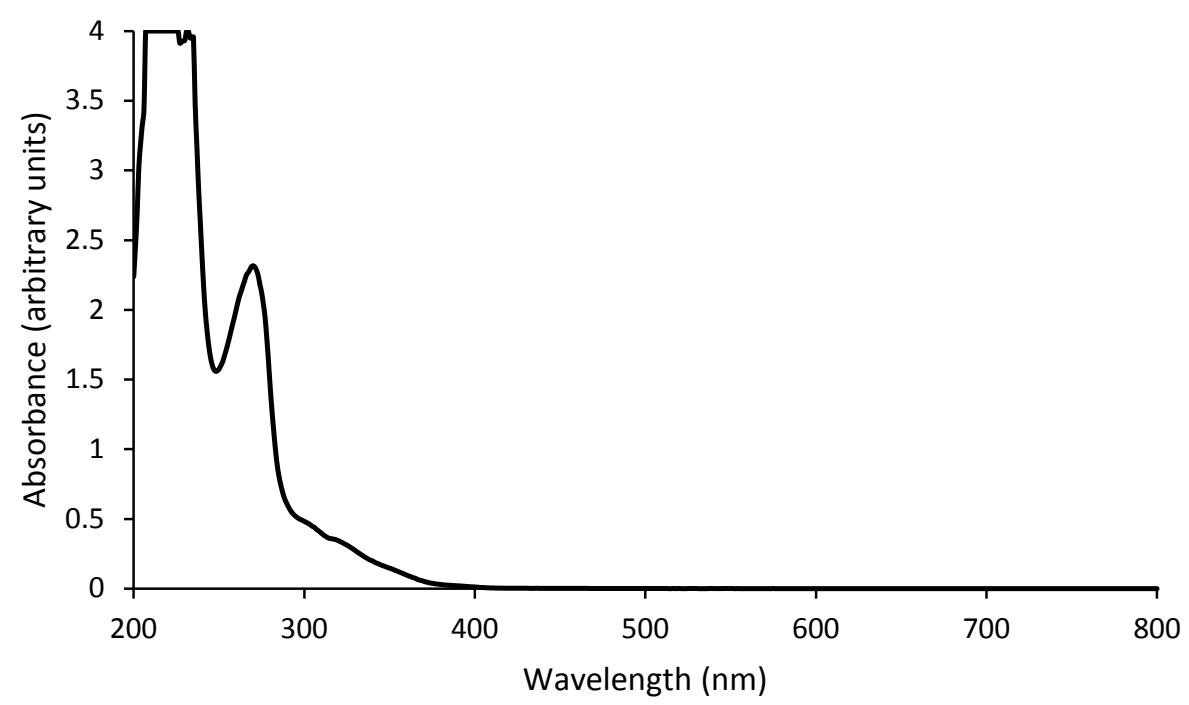

Figure S8. UV-visible spectrum of Eu ${ }^{\mathrm{II}} \mathbf{2}$ in methanol. 


\section{Excitation and Emission Spectra}

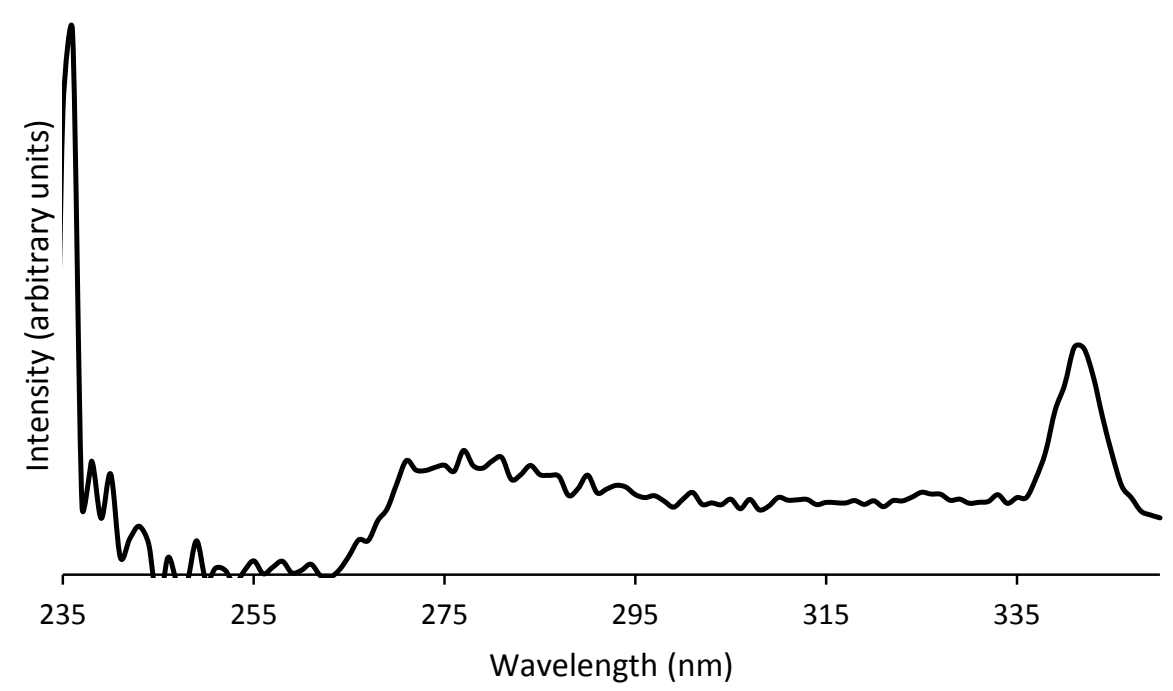

Figure S9. Excitation spectrum of $\mathrm{YbI}_{2}$ in $N, N$-dimethylformamide.

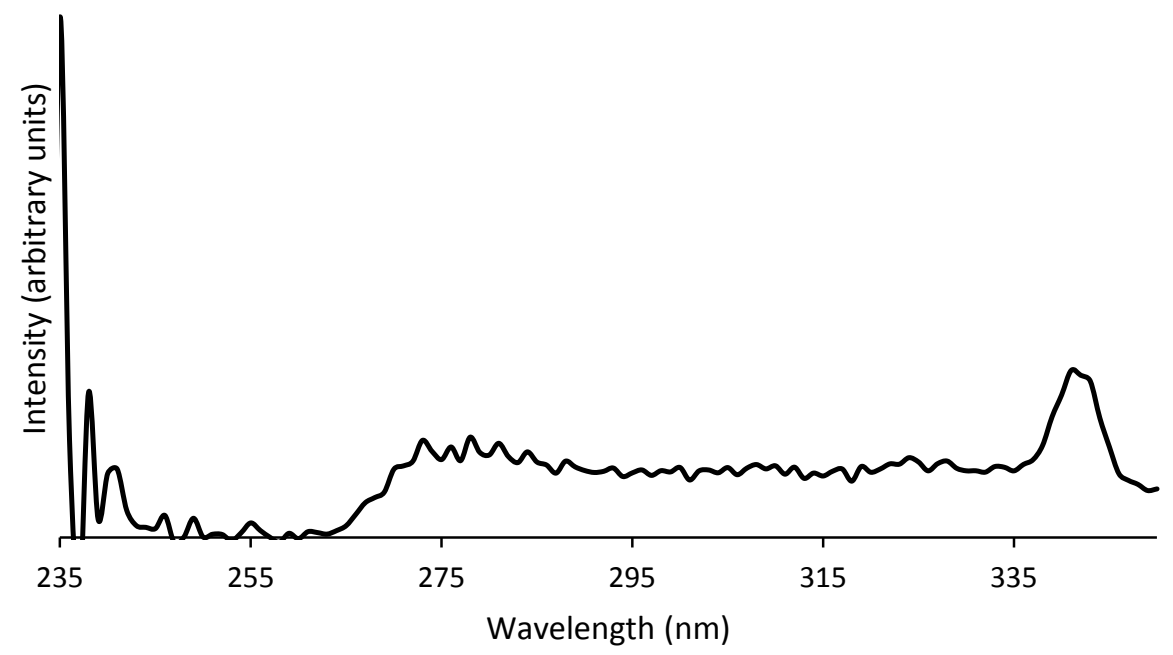

Figure S10. Excitation spectrum of $\mathrm{Yb}^{\mathrm{II}} \mathbf{4}$ in $N, N$-dimethylformamide. 


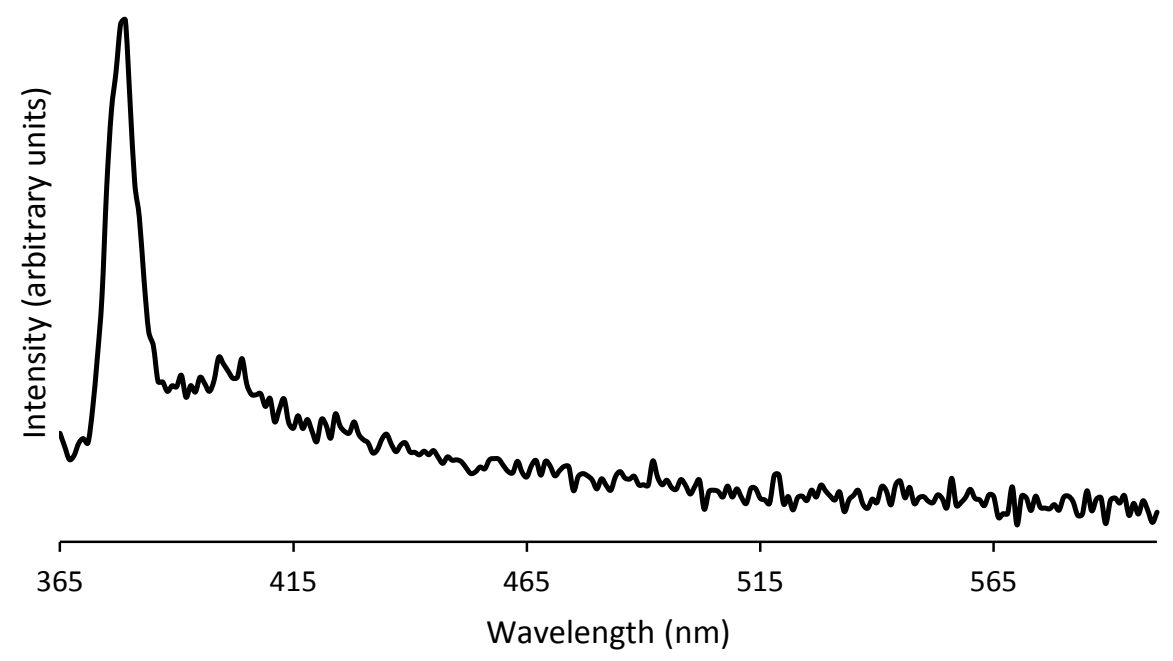

Figure S11. Emission spectrum of $\mathrm{YbI}_{2}$ in $N, N$-dimethylformamide.

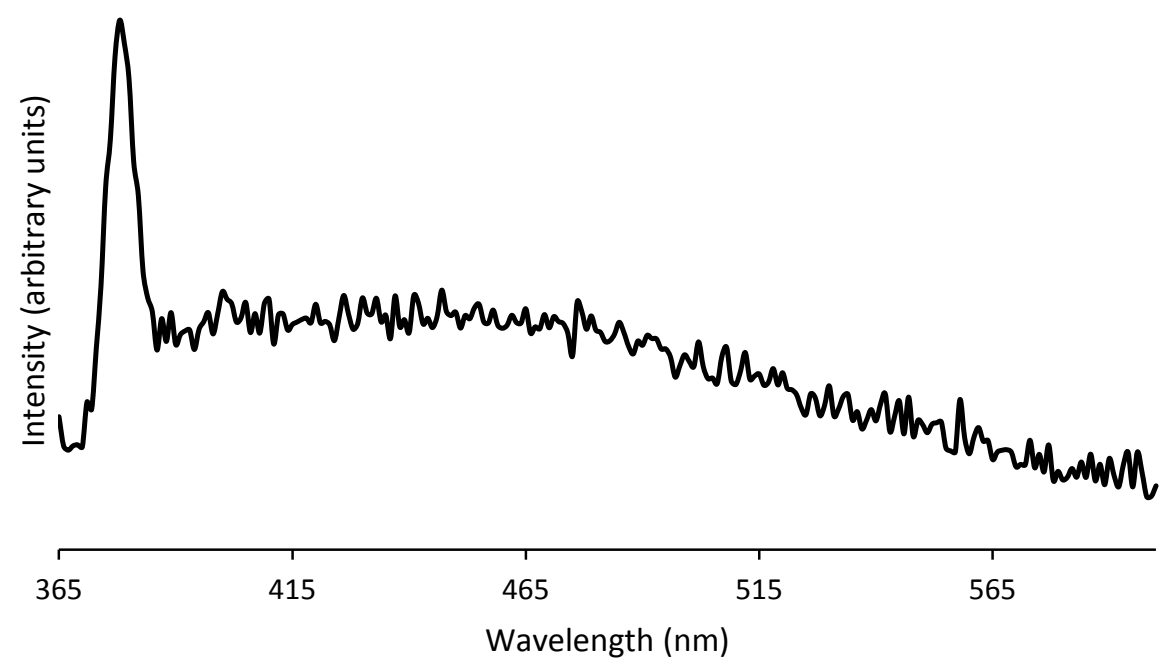

Figure S12. Emission spectrum of $\mathrm{Yb}^{\mathrm{II}} \mathbf{4}$ in $N, N$-dimethylformamide. 


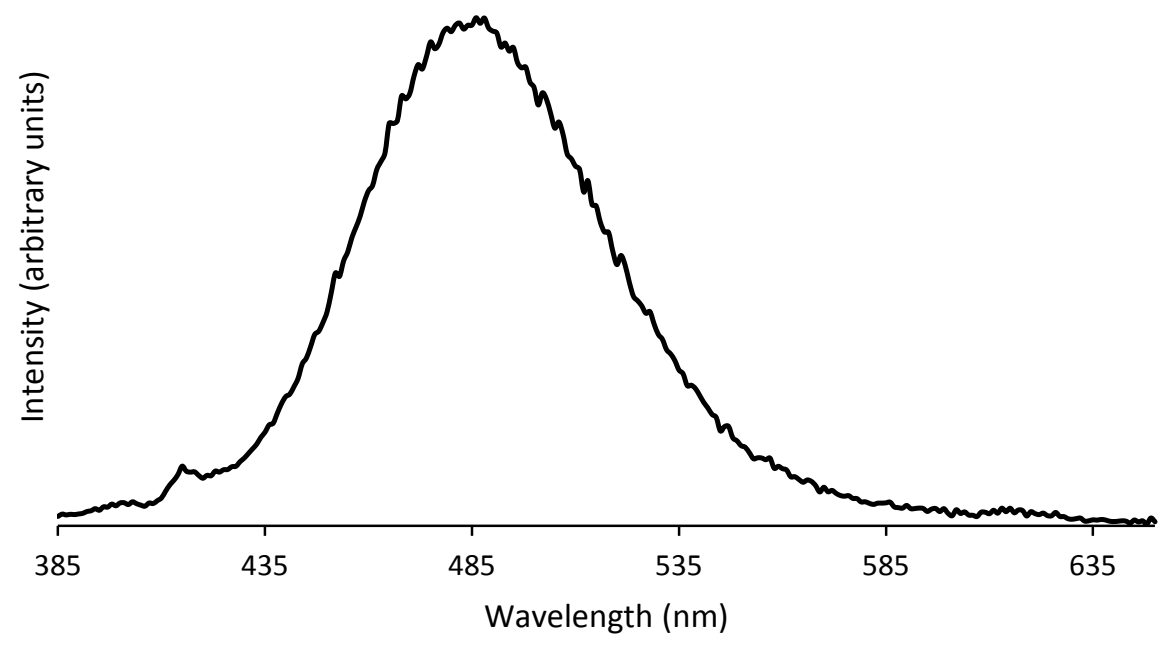

Figure S13. Emission spectrum of EuI 2 in methanol.

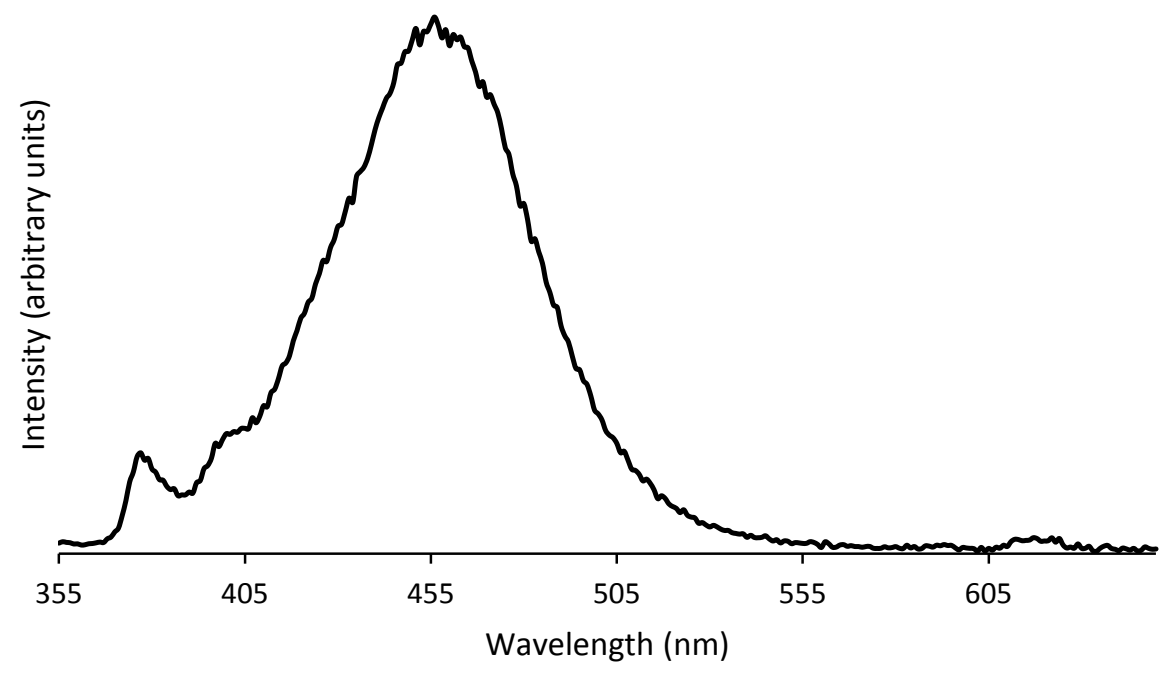

Figure S14. Emission spectrum of Eu ${ }^{\mathrm{II}} 2$ in methanol. 
Jenks et al.

Supporting Information

\section{Cyclic Voltammograms}

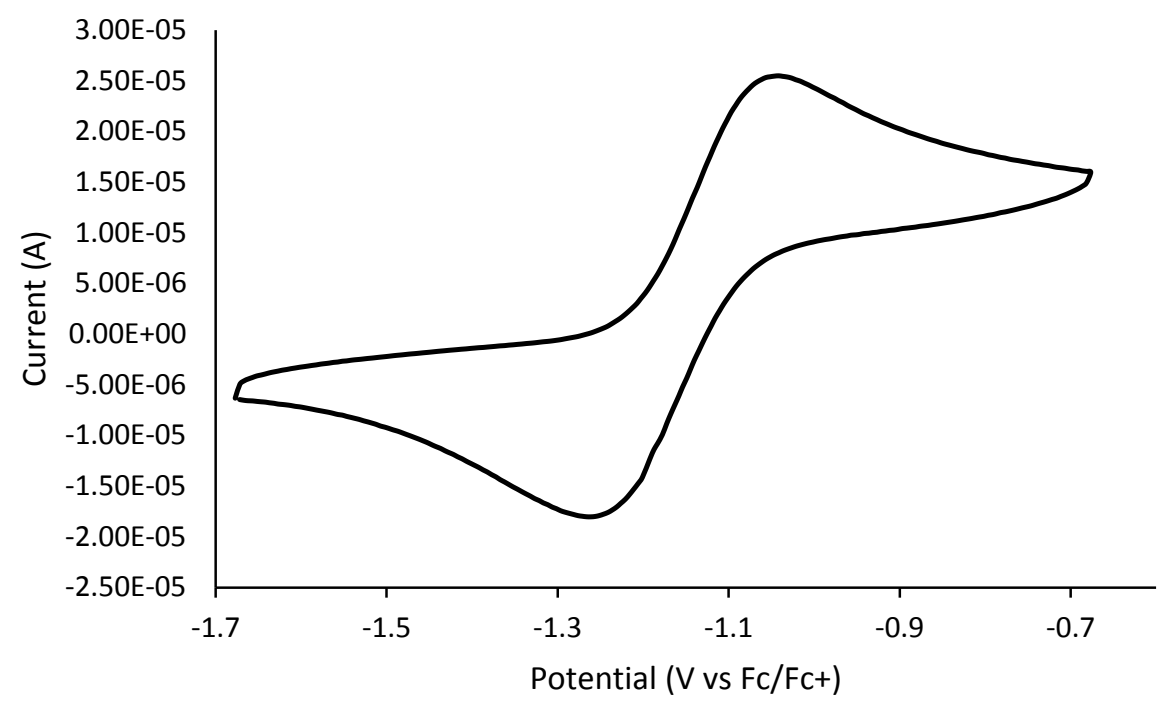

Figure S15. Cyclic voltammogram of $\mathrm{EuI}_{2}$ in $N, N$-dimethylformamide.

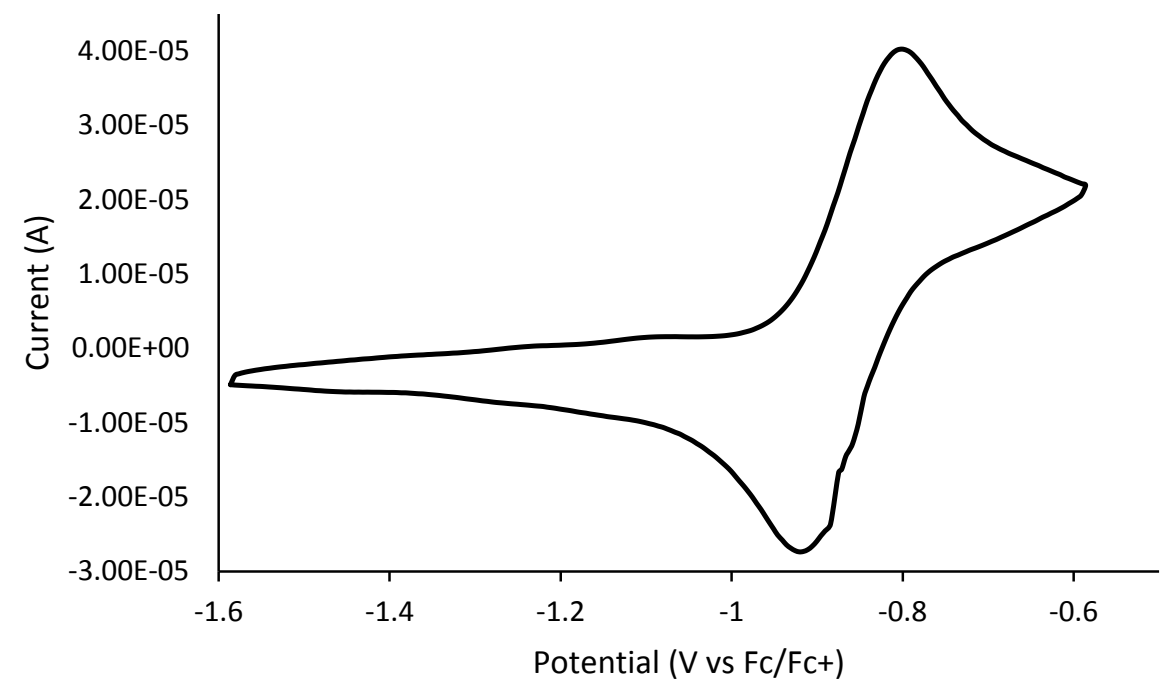

Figure S16. Cyclic voltammogram of $\mathrm{Eu}^{\mathrm{II} 3}$ in $N, N$-dimethylformamide. 
Jenks et al.

Supporting Information

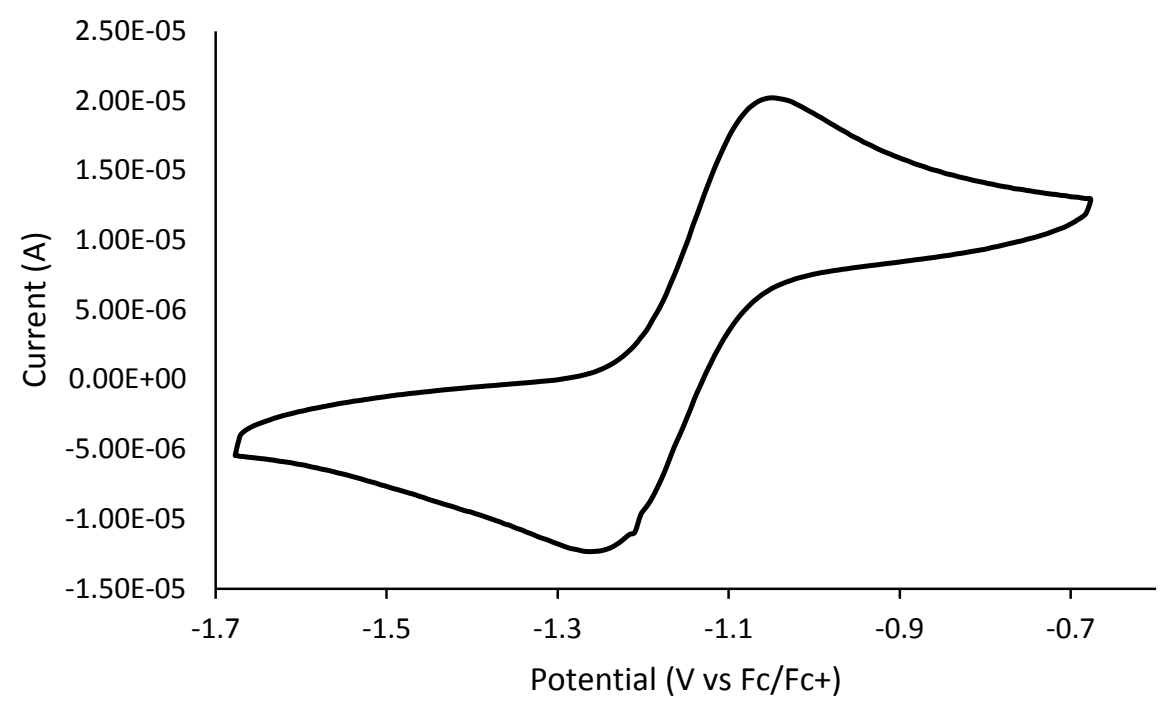

Figure S17. Cyclic voltammogram of Eu ${ }^{\mathrm{II}} 4$ in $N, N$-dimethylformamide.

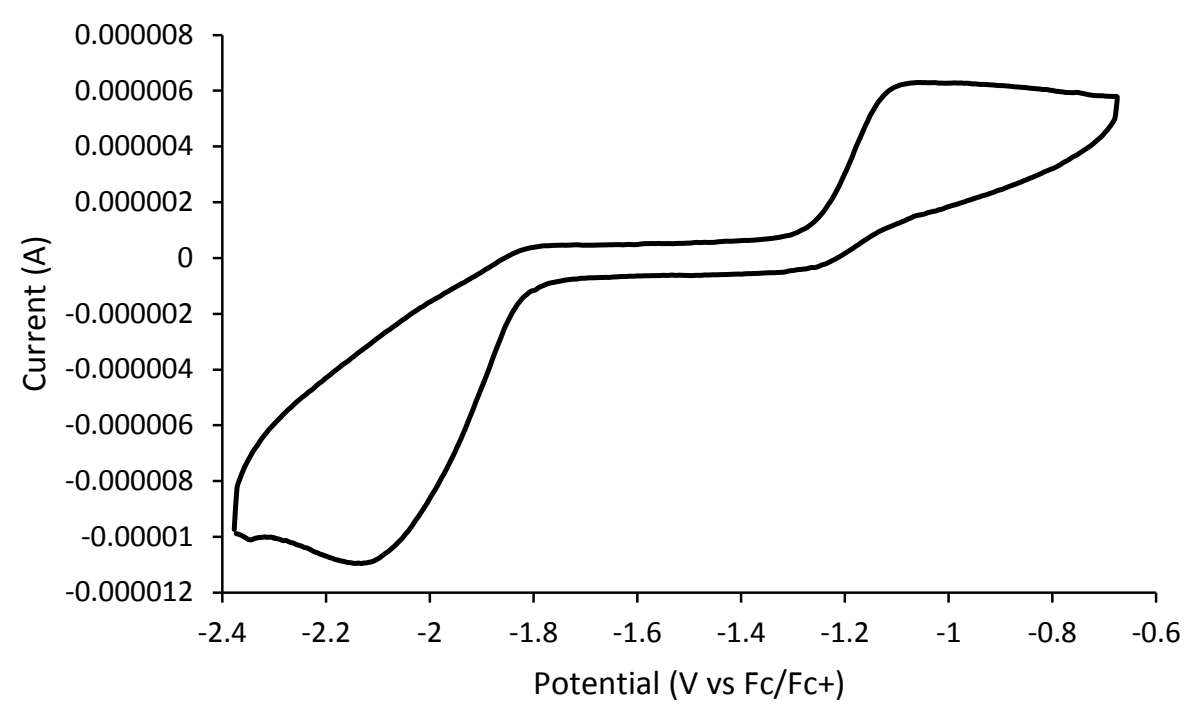

Figure S18. Cyclic voltammogram of oxidized $\mathrm{Yb}^{\mathrm{II}} \mathbf{1}$ in $N, N$-dimethylformamide. 
Jenks et al.

Supporting Information

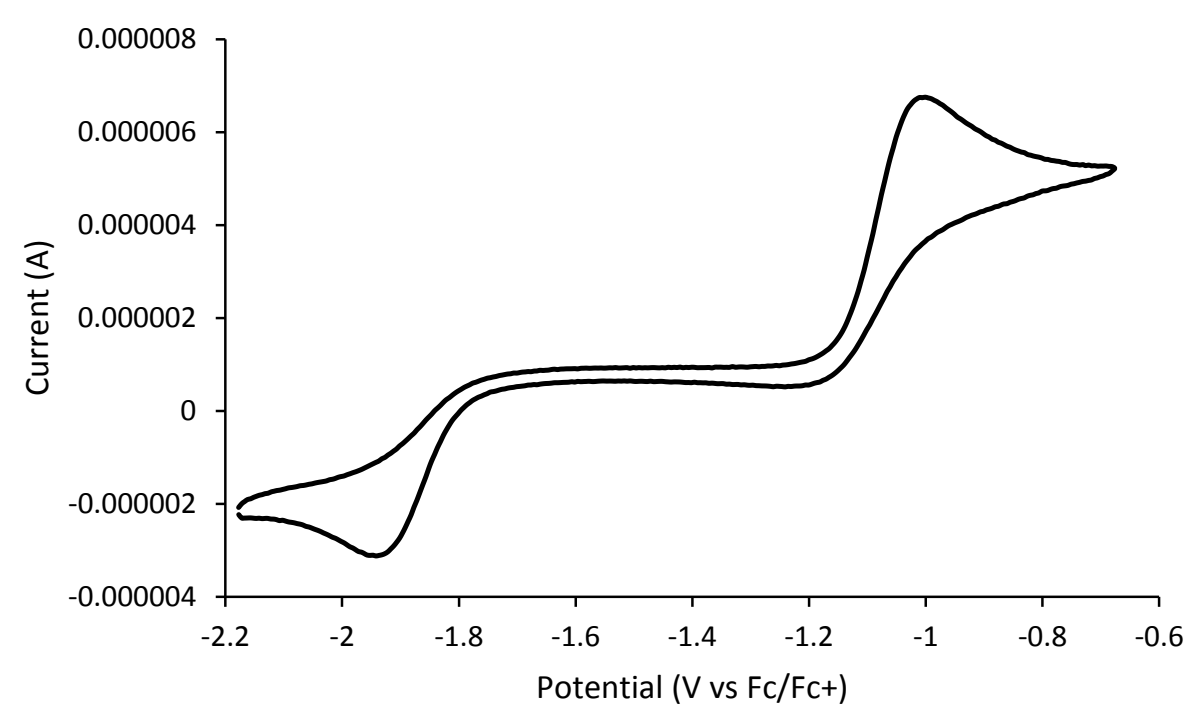

Figure S19. Cyclic voltammogram of $\mathrm{Yb}^{\mathrm{II}} \mathbf{2}$ in $N, N$-dimethylformamide with a scan rate of 10 $\mathrm{mV} / \mathrm{s}$.

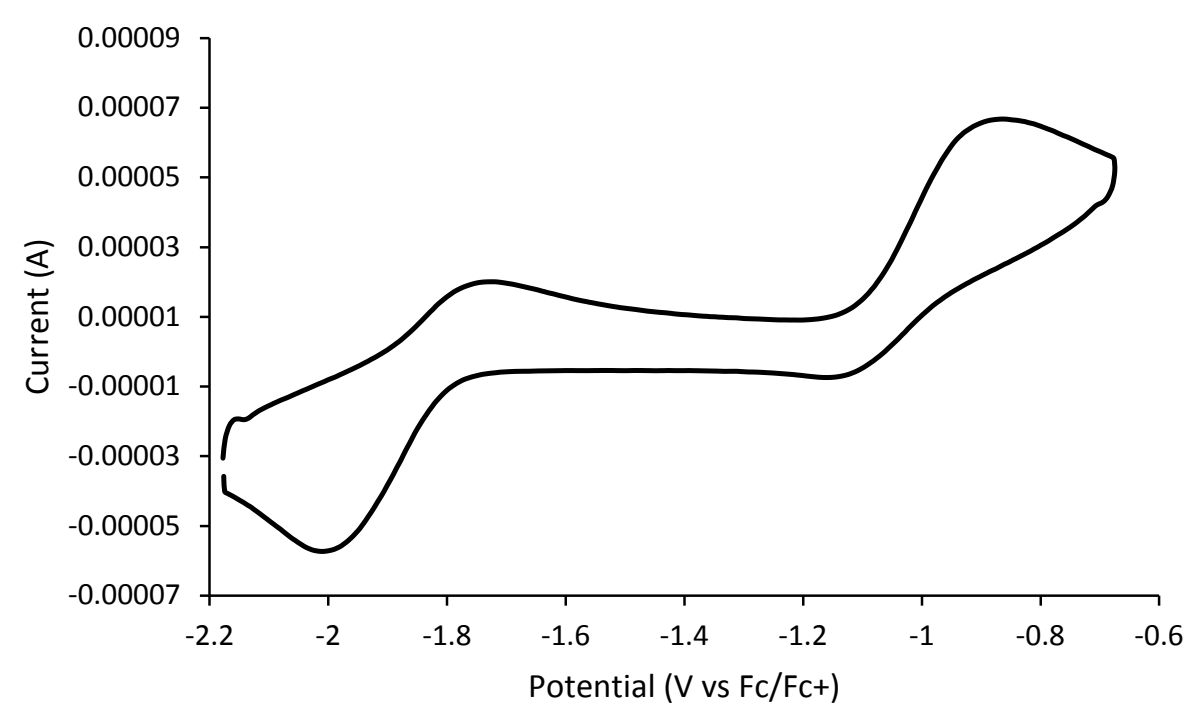

Figure S20. Cyclic voltammogram of $\mathrm{Yb}^{\mathrm{II}} 2$ in $N, N$-dimethylformamide with a scan rate of $1 \mathrm{~V} / \mathrm{s}$. 
Jenks et al.

Supporting Information

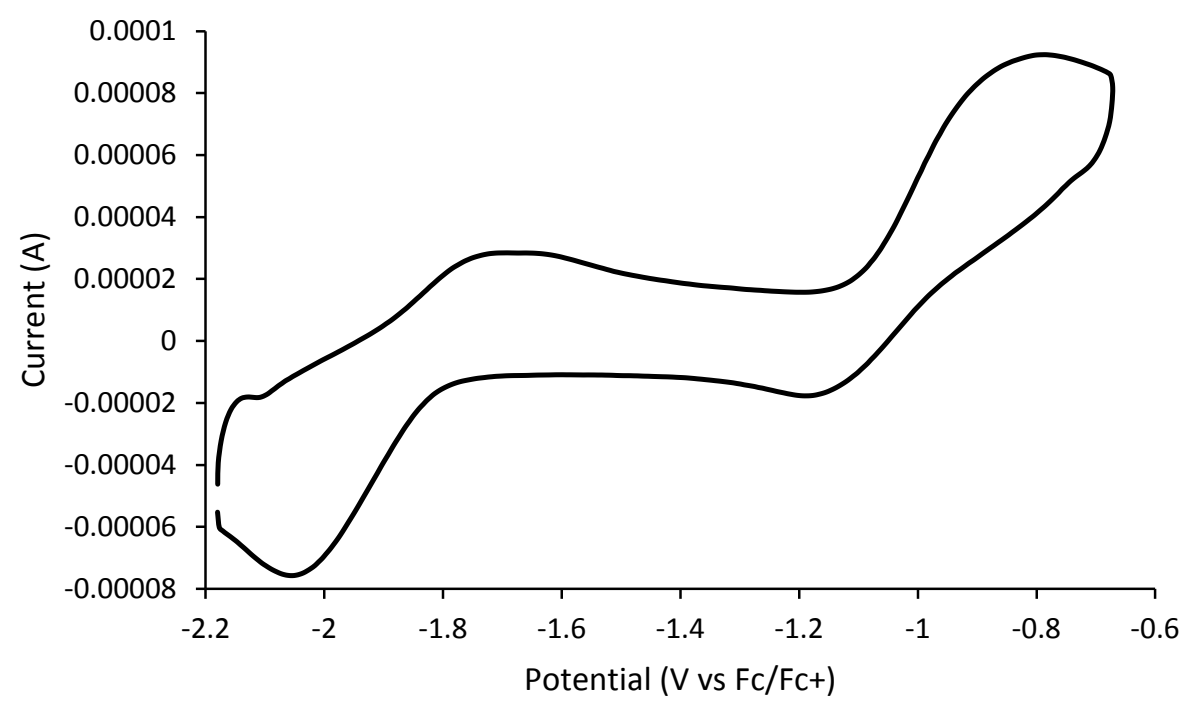

Figure S21. Cyclic voltammogram of $\mathrm{Yb}^{\mathrm{II}} 2$ in $N, N$-dimethylformamide with a scan rate of $2 \mathrm{~V} / \mathrm{s}$.

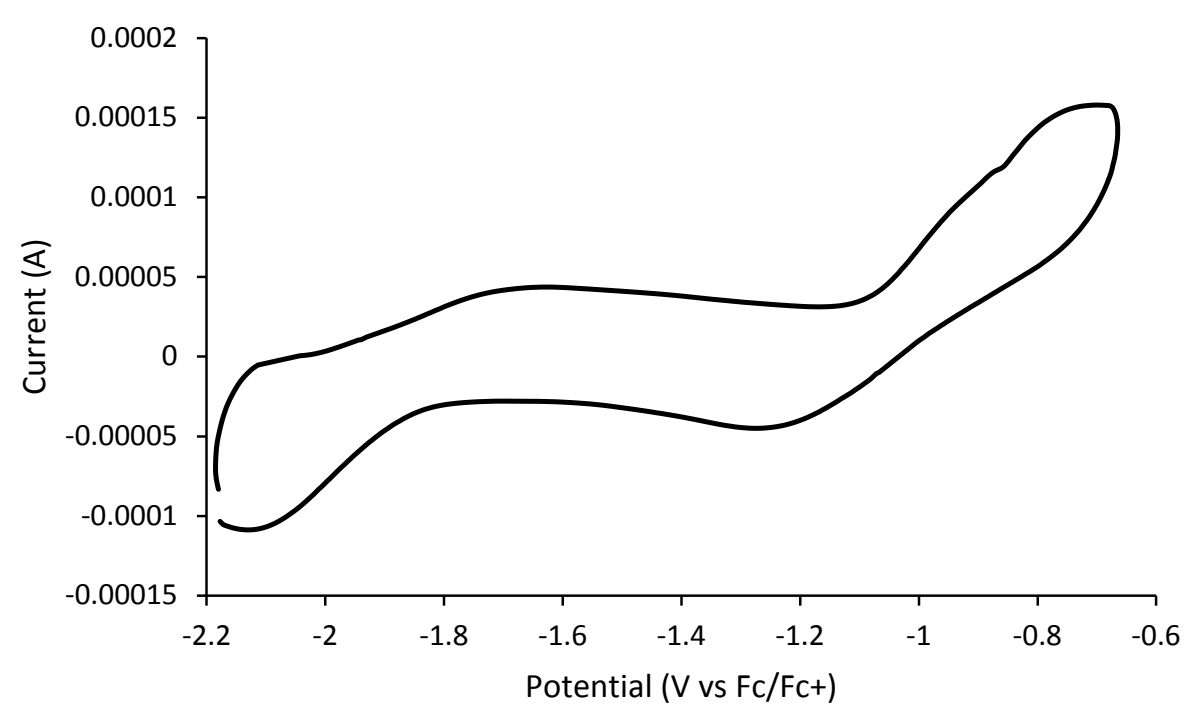

Figure S22. Cyclic voltammogram of $\mathrm{Yb}^{\mathrm{II}} 2$ in $N, N$-dimethylformamide with a scan rate of $5 \mathrm{~V} / \mathrm{s}$. 